\title{
Bryophyte flora of Hunan Province, China. 12. Diphysciaceae (Musci)
}

\author{
Virpi Karén, Johannes Enroth* \& Timo Koponen
}

\begin{abstract}
Department of Biosciences and the Botanical Museum, P.O. Box 7, Fl-00014 University of Helsinki, Finland ( ${ }^{*}$ corresponding author's e-mail: johannes.enroth@helsinki.fi)
\end{abstract}

Received 26 Oct. 2009, revised version received 18 Jan. 2010, accepted 21 Jan. 2010

Karén, V., Enroth, J. \& Koponen, T. 2010: Bryophyte flora of Hunan Province, China. 12. Diphysciaceae (Musci). - Ann. Bot. Fennici 47: 208-214.

The genus Diphyscium (Diphysciaceae, Bryophyta) has three species in the Hunan Province of China: D. fulvifolium Mitt., D. mucronifolium Mitt. and D. chiapense D.H. Norris subsp. unipapillosum (Deguchi) T.-Y. Chiang \& S.-H. Lin. Diphyscium fulvifolium is clearly the most common species. The other two taxa are reported for the first time from Hunan, and D. chiapense subsp. unipapillosum also from Jiangxi; in China, it was previously known only from Taiwan. The three species are illustrated in line drawings. A previous record of D. foliosum (Hedw.) Mohr was based on a misidentified specimen and the species is thus excluded from the flora of Hunan.

Key words: Diphyscium, distribution, flora, habitat ecology, Hunan, mosses, nomenclature, taxonomy

This is the twelfth part in a series dealing with the bryophyte flora of Hunan Province in China. The previous paper in the series was by Guo et al. (2007). These papers are essentially based on the specimens collected during a series of excursions to eight Hunanese nature reserves from 1997 to 2001 by the Department of Ecology and Systematics (as of 2010: Department of Biosciences) and the Botanical Museum of the University of Helsinki in cooperation with the Forest Botanical Garden of the Hunan Province.

Relevant background information of Hunan and earlier studies of its bryoflora was given by Rao et al. (1997). The vegetation and geology of Mangshan Nature Reserve and Wulingyuan Global Cultural Heritage Area were described in Koponen et al. (2000), and those of Taoyuandong and Yankou Nature Reserves and Badagongshan (the 1998 and 1999 localities, respectively numbered 39-55 and 86-88) and Hupingshan National Nature Reserves in Koponen et al. (2004). The nature and collecting localities in Badagongshan and Daweishan (visited in 2000), and Shunhuangshan and Yunshan (visited in 2001) will be described in a forthcoming paper (but see Högmander \& Jie 2000 for general information on the reserves). The method for estimating the frequencies, primevity index and the basis for phytogeography and distribution elements were presented by Koponen et al. (2004), and a summary of the previous 11 papers of the Hunan series by Koponen and Piippo (2007).

The present paper treats Diphyscium, the single genus in the moss family Diphysciaceae (Magombo 2002) and monographed by Mago- 
mbo (2003), whose species concepts we follow. Magombo (2003) recognized in Diphyscium a total of 15 species, of which seven occur in China. In the check-list by Rao et al. (1997), which reported the situation prior to the Helsinki research group studies, only $D$. fulvifolium var. leveillei was recorded for Hunan. As Magombo (2003, "laveillei") pointed out in his monograph of the Diphysciaceae, that variety has not been validly published and is a nomen nudum. Diphyscium foliosum was reported from Hunan by Wang et al. (2005). The report was based on one specimen, which we borrowed from $\mathrm{PE}$ and it turned out to be misidentified.

A complete set of the cited specimens is kept in the Botanical Museum of the University of Helsinki (H) and a second set in the herbarium of the Forest Botanical Garden of the Hunan Province in Changsha. Further sets are distributed as exchange from $\mathrm{H}$.

\section{Key to species of Diphyscium in Hunan}

1. Laminal cells smooth; stomata lacking D. mucronifolium

1. Laminal cells mammillose or papillose; phaneroporous stomata near capsule orifice

2. Laminal cells unipapillose or mammillose D. chiapense subsp. unipapillosum

2. Laminal cells pluripapillose (often appearing bipapillose in cross-sections) D. fulvifolium

Diphyscium chiapense D.H. Norris subsp. unipapillosum (Deguchi) T.-Y. Chiang \& S.-H. Lin (Fig. 1 and Appendix)

Bot. Bull. Acad. Sin. 42: 217. 2001. - D. unipapillosum Deguchi, J. Jap. Bot. 59: 97. 1984.

D. buckii B.C. Tan, Bryologist 93: 429. 1990. - Synonymized with $D$. chiapense by Deguchi et al. (1997).

Plants ca. 5-15 mm high, mostly in small patches. Stem central strand present. Leaves curled when dry, spreading when wet, ca. 3-7 $\times$ 0.5-1.0 mm, oblong-lanceolate to ligulate or lingulate; apex rounded, rarely acute, mucronate to apiculate; lamina unistratose at base, bistratose above; median laminal cells rounded to quadrate, 4-12 $\mu \mathrm{m}$ in diameter, mammillose or unipapillose; basal cells rectangular, 15-60 ×5-13 $\mu \mathrm{m}$, hyaline, smooth; leaf margins entire below,

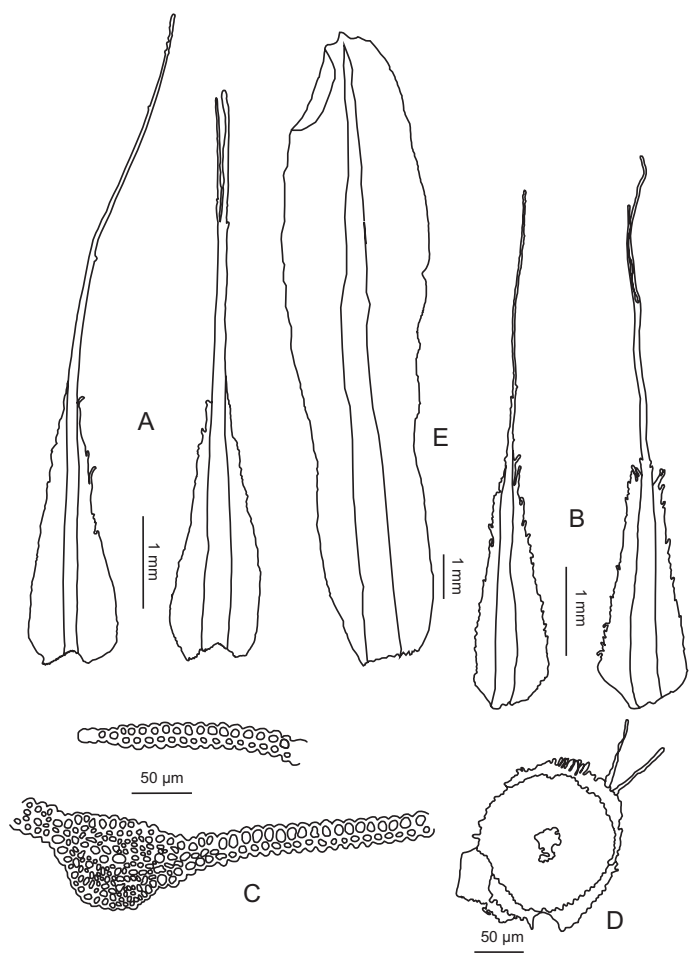

Fig. 1. Diphyscium chiapense subsp. unipapillosum (from Enroth 70484). - A: Outer perichaetial leaves. - B: Inner perichaetial leaves. - C: Cross-section through median part of leaf (costa region and leaf margin separately). - D: Cross-section through stem. - E: Leaf.

crenulate above, unistratose; costa percurrent to shortly excurrent, usually with a distinct dorsal and ventral stereid band and between them 1-2 layers of guide cells, occasionally cells weakly differentiated. Dioicous, male plants usually smaller than female plants. Perichaetial leaves oblong-lanceolate or ovate-lanceolate, awn longexcurrent, smooth; outer leaves 4-6 $60.4-0.5$ $\mathrm{mm}$, margins entire below, crenulate above; inner leaves 3-7 × 0.3-0.5 mm, margins entire below, crenulate and dissected at apex. Seta ca. 0.2-0.3 mm long. Capsule oblique and asymmetric, with one side straight, one bulging, ca. $3.0-4.0 \times 1-2 \mathrm{~mm}$, mostly abruptly narrowed at base and orifice; exothecial cells on bulging surface collenchymatous, irregular, smooth, walls irregularly wavy, exothecial cells on non-bulging surface mostly hexagonal, smooth, thick- and straight-walled; stomata near orifice, phaneroporous. Operculum ca. $0.5 \mathrm{~mm}$ long, conical, cells 


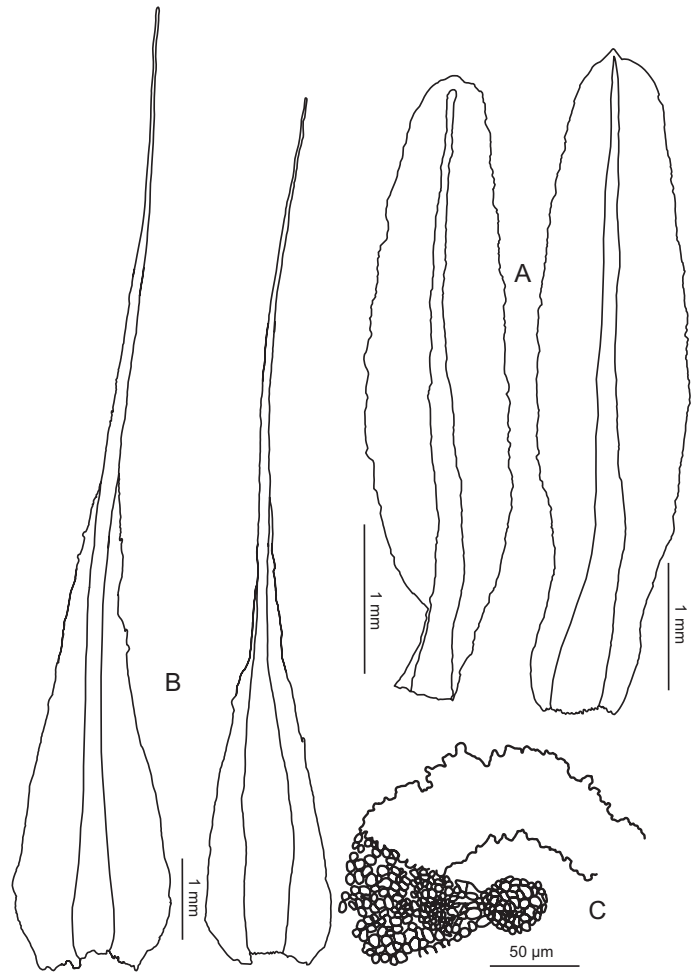

Fig. 2. Diphyscium fulvifolium (from Enroth 70603). - A: Leaves. - B: Outer perichaetial leaves. - C: Cross-section through stem.

thick-walled, smooth. Annulus with one to three layers of thick-walled cells. Peristome present. Calyptra cucullate, cells thick-walled, smooth. Spores $8-15 \mu \mathrm{m}$ in diameter, rounded, papillose.

Diphyscium chiapense subsp. unipapillosum can be identified by the distinctly mammillose to unipapillose laminal cells, despite some variation in the degree of the mammillosity or papillosity. Deguchi et al. (1997) considered this taxon a synonym of $D$. chiapense, but Chiang and Lin (2001) recognized it at the subspecific level, a notion also used by Magombo (2003) and Wang et al. (2005). The morphological character that distinguishes $D$. chiapense subsp. unipapillosum from the Central American D. chiapense is the consistently smooth subula in the inner perichaetial leaves.

Diphyscium chiapense subsp. unipapillosum has a fairly narrow total range (see below), and represents the "Southeast Asian temperate to warm temperate element" as defined by Kopo- nen et al. (2004). It thrives well in disturbed or man-made habitats. One of our specimens was growing on the base of a tree, one on sand by a brook and six on cliffs or outcrops on a thin humus layer. In China previously known only from Taiwan, it is here reported for the first time from Hunan and Jiangxi. Primevity index: 1/5/2. Frequency in Hunan: rare.

Range In Hunan (first records): Mangshan. 3b. Koponen, Huttunen \& Rao 51571. Wulingyuan. 17b. Koponen, Huttunen \& Rao 52450. Shunhuangshan. S3. Enroth 70484. S9. Enroth 70758. Yuankou. 74c. Koponen 60039, 60043. 74d. Koponen 59846.75a. Koponen 59352.

RANGe In China (Wang et al. 2005: 293, fig. 1): Taiwan, Hunan, Jiangxi. - SPECIMEN EXAMined from Jiangxi (first record): Yanshan Co., Wuishan National Nature Reserve, warm temperate (subtropical) zone, $1110 \mathrm{~m}$, on soil, X.1993 Mengcheng Ji 4626 (H).

Total RANGe (Magombo 2003: fig. 5): Asia (Japan, Taiwan, Philippines). New to continental China.

\section{Diphyscium fulvifolium Mitt. (Figs. 2, 3 and Appendix)}

Trans. Linn. Soc. London, Bot. 2: 143. 1891. - Webera fulvifolia (Mitt.) Broth., Nat. Pflanzenfam. 1(3): 664. 1904.

Diphyscium rotundatifolium C.K. Wang \& S.H. Lin, Ann. Missouri Bot. Garden 61: 526. 1974. - Synonymized by Iwatsuki (1976).

Diphyscium fulvifolium var. leveillei Thér. in Broth., Ann. Naturhist. Mus. Wien 38: 149. 1925, nom. nud. Original collection: China. "Prov. Hunan autro-occ.: In monte Yün-schan prope urbem Wukang, in silva elata frondosa umbrosa", 1180 m, 15.VIII.1918 Handel-Mazzetti "Diar. Nr. 2621" (H-BR 1299017). - Redfearn et al. (1996) erroneously cited it from Hubei.

Plants ca. 4-15 $\mathrm{mm}$ high, growing in small patches. Stem central strand weak or lacking. Leaves curled when dry, spreading when wet, $3-8 \times 0.6-1.0 \mathrm{~mm}$, spathulate to ligulate; apex rounded, mucronate or apiculate; lamina unistratose at base, bistratose above; median laminal cells rounded to quadrate, 5-10 $\mu \mathrm{m}$ in diameter, mostly pluripapillose; basal cells rectangular, 20-60 × 6-16 $\mu \mathrm{m}$, hyaline, smooth; leaf margins entire below, crenulate above, uni- or bistratose; costae mostly percurrent, with a dorsal and ventral stereid band and between them 1-2 two layers of guide cells. Dioicous, male plants smaller than female plants. Perichaeti- 
cal leaves lanceolate, awn excurrent, papillose; outer leaves 4-7 ×0.3-0.7 mm, margins entire or slightly dissected; inner leaves 3-8 $\times 0.3-0.5$ $\mathrm{mm}$, margins entire below, laciniate to ciliate at apex. Seta ca. 0.2-0.3 mm long. Capsule oblong-ovoid, oblique and asymmetric, 3-5 $\times$ 0.9-2 mm, abruptly narrowed at base and orifice; exothecial cells on bulging surface collenchymatous, irregular and with wavy walls, smooth, exothecial cells on non-bulging surface penta- or hexagonal, smooth, thick- and straight-walled; stomata near orifice, phaneroporous. Operculum ca. 1.5-2.0 mm, cucullate, conical, obtuse, cells thick-walled, smooth. Annulus with 1-3 layers of thick-walled cells. Peristome present. Calyptra conical, cucullate, cells thick-walled, smooth. Spores $8-13 \mu \mathrm{m}$ in diameter, rounded, papillose.

Magombo (2003) failed to mention the variability in the papillosity of the laminal cells. Usually they are distinctly pluripapillose, but some of the cells can be practically unipapillose or mammillose. The apices of the perichaetial leaves are also fairly variable regarding how strongly ciliate or dissected they are.

Diphyscium fulvifolium is by far the commonest species of its genus in Hunan, and in fact in the whole of China (Wang et al. 2005). The collections were made between 390 and $1920 \mathrm{~m}$ and the species was found in each of the eight nature reserves visited (cf. Koponen et al. 2004). The habitats ranged from fully exposed to fully shaded. The specimens were collected on cliffs or outcrops (28), humus (10), tree bases (6), sand (3) and gravel (1). Even when growing on cliffs or tree bases, a thin layer of humus seems to be necessary for the species. Diphyscium fulvifolium thrives well in disturbed habitats such as road sides.

Diphyscium fulvifolium is distributed in eastern Asia (see below) and it represents the "Southeast Asian temperate to warm temperate element" as defined by Koponen et al. (2004). Primevity index 18/17/13. Frequency in Hunan: rather common.

Range in Hunan: Badagongshan. 45 (1998). Koponen, Huttunen, Piippo \& Rao 55512. 45 (2000) Virtanen 61513. 88a. Rao 59067, 59071. 95. Virtanen 61485. Daweishan. DAW17. Virtanen 61778. DAW20. Enroth 64660 \& von Bonsdorff, Virtanen 61729. DAW24b. Virtanen 62213,

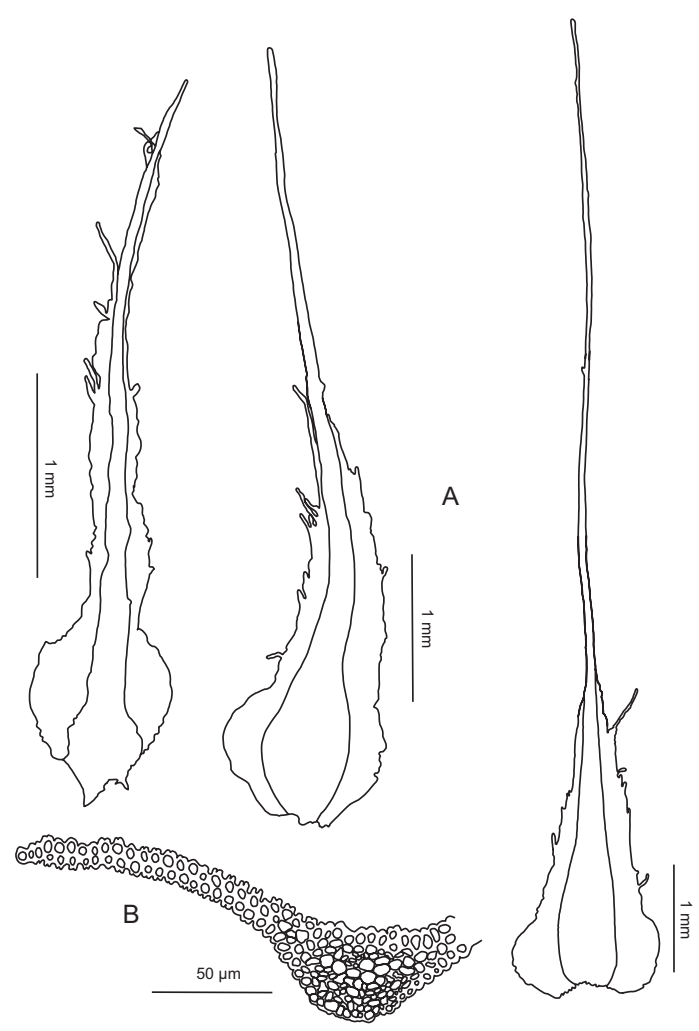

Fig. 3. Diphyscium fulvifolium (from Enroth 70603). A: Three inner perichaetial leaves. - B: Cross-section through median part of leaf.

62216. Mangshan. 3a. Koponen, Huttunen \& Rao 51766, 51859. 5. Koponen, Huttunen \& Rao 51355. 6. Huttunen \& Rao 51233. 7c. Koponen, Huttunen \& Rao 50740. 7d. Koponen, Huttunen \& Rao 51052.9a. Koponen, Huttunen \& Rao 49088, 49508, 49177. 10c. Koponen, Huttunen \& Rao 51279 13. Koponen, Huttunen \& Rao 50986. 14a. Koponen, Huttunen \& Rao 49130. 14b. Koponen, Huttunen \& Rao 49317. Wulingyuan. 18a. Koponen, Huttunen \& Rao 52564. 18e. Koponen, Huttunen \& Rao 53049. Shunhuangshan. S2b. Enroth 71109, 71111, 71112, 71141, 71142. S6. Enroth 70603, 70605. S7. Enroth 70631. S10. Enroth 70793. S14. Enroth 71001, 71023. S16. Enroth 71042. Taoyuandong. 25a. Koponen, Huttunen, Piippo \& Rao 56860. 27. Koponen, Huttunen, Piippo \& Rao 55212, 56505. 28. Koponen, Huttunen, Piippo \& Rao 56560. 34. Koponen, Huttunen, Piippo \& Rao 57017. 37. Koponen, Huttunen, Piippo \& Rao 56676. Yuankou. 74d. Koponen 59864. 76b. Koponen 59978. 78c. Koponen 59687. 79a. Koponen 59516. Yunshan. Y7a. Enroth 70127.

RANGe IN China (Wang et al. 2005: 295, fig. 3): Anhui, Chongqing, Fujian, Guangdong, Guizhou, Hubei, Hunan, Jiangsu, Jiangxi, Taiwan, Yunnan.

Total RAnge (Magombo 2003: fig. 19): Asia (China, Japan, Korea, Philippines, Taiwan). 

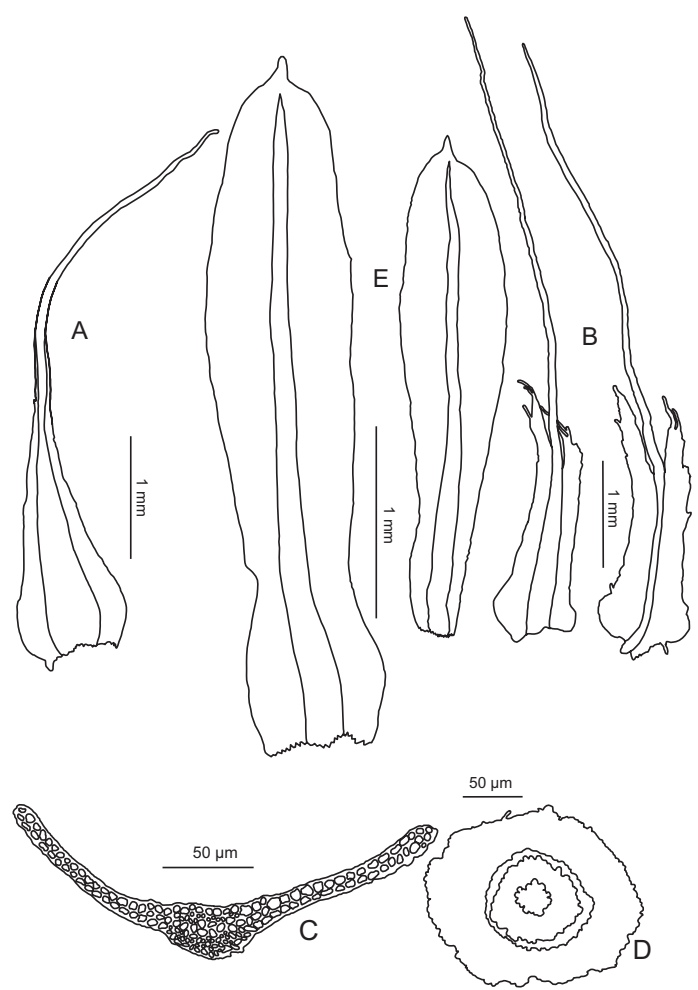

Fig. 4. Diphyscium mucronifolium (from Koponen, Huttunen \& Rao 50598). - A: Outer perichaetial leaf. - B: Inner perichaetial leaves. - C: Cross-section through median part of leaf. - D: Cross-section through stem. - E: Leaves.

Diphyscium mucronifolium Mitt. (Fig. 4 and Appendix)

in Dozy \& Molk., Bryol. Jav. 1: 35. 1855. - Webera mucronifolia (Mitt.) Broth., Nat. Pflanzenfam. 1(3): 664. 1904.

Diphyscium involutum Mitt., J. Proc. Linn. Soc. Bot., Suppl. 1: 149. 1859. - Webera involuta (Mitt.) Broth., Nat. Pflanzenfam. 1(3): 664. 1904.

Plants ca. 5-20 mm high, growing in small patches, olive-green when moist. Stem central strand present. Leaves contorted when dry, spreading when wet, 3-6 $60.3-1.0 \mathrm{~mm}$, oblong-lanceolate to ligulate; apex obtuse or broadly acute, mucronate or apiculate; lamina unistratose at base, bistratose above, cells thickwalled; median laminal cells rounded to quadrate, 5-12 $\mu \mathrm{m}$ in diameter, smooth; basal cells rectangular, $15-50 \times 4-10 \mu \mathrm{m}$ wide, hyaline, smooth, leaf margins entire throughout, $2-4$ cells thick; costa percurrent or shortly excurrent, with a dorsal and ventral stereid band and between them 1-2 layers of guide cells, orange-brown, often hyaline at base. Dioicous, male plants smaller than or the same size as female plants. Perichaetial leaves lanceolate, awn long excurrent, smooth; outer leaves 3-8 ×0.4-1.0 mm, margins entire at base, entire or minutely dissected above; inner leaves 2.5-8.0 ×0.3-0.6 mm, margins entire at base, dissected or laciniate above. Seta to $0.3 \mathrm{~mm}$ long. Capsule oblongovate, obliquely asymmetric, 3-5 $31.0-2.5 \mathrm{~mm}$, abruptly narrowed at base and orifice; exothecial cells on bulging surface collenchymatous, irregular and with wavy walls, smooth, on non-bulging surface cells penta- or hexagonal, smooth, thick- and straight-walled; stomata lacking. Operculum ca. $1 \mathrm{~mm}$ long, conical, obtuse, cells thick-walled, smooth. Annulus with 1-3 layers of thick-walled cells. Peristome present. Calyptra conical, cells thick-walled, smooth. Spores 8-15 $\mu \mathrm{m}$ in diameter, rounded, papillose.

Diphyscium mucronifolium is readily distinguished by the smooth laminal cells and consistent absence of stomata in the capsules. It was collected only three times in Hunan. All of the collections were made in Mangshan, the southernmost Nature Reserve in Hunan, with a subtropical climate (cf. Koponen et al. 2000). The specimens were growing on cliff (2) and outcrop (1) in moist and semi-shaded habitats between 1225 and $1280 \mathrm{~m}$ in relatively primeval forests.

The total range of $D$. mucronifolium is strongly disjunct. The main distribution area is in eastern and southeastern Asia (and southwards to northern Australia), but the species also occurs in the southern Appalachian region in North America. It thus belongs in the "Disjunct elements" of Koponen et al. (2004), and more specifically in the Eastern Asia-Atlantic North America element of Iwatsuki $(1958,1992)$. Primevity index: 3/0/0. Frequency in Hunan: rare.

Range In Hunan (first record): Mangshan. 9a. Koponen, Huttunen \& Rao 49437. 12a. Koponen, Huttunen \& Rao 49597. 12b. Koponen, Huttunen \& Rao 50598.

RANGe IN China (Wang et al. 2005: 298, fig. 6): Chongqing, Fujian, Guangdong, Hainan, Taiwan, Yunnan, Hunan.

Total RANGe (Magombo 2003: fig. 36): Australia (Queensland), tropical and subtropical Asia, southeastern North America. 


\section{Excluded species}

\section{Diphyscium foliosum (Hedw.) Mohr}

Index Mus. Pl. Crypt.: 3. 1803.

This species was reported from Hunan by Wang et al. (2005) based on the specimen $Q .-R$. Liu $Q R-32$. We borrowed it from PE and it turned out to represent D. fulvifolium. Diphyscium foliosum can be distinguished from $D$. fulvifolium by the costa which ends below the leaf apex, by the stomata that occur at the base of the capsule (not at the orifice), and by the obtuse or acute instead of mucronate or apiculate leaf apex (Magombo 2003). Diphyscium foliosum is thus excluded from the flora of Hunan. It is in China known from Guizhou, Sichuan, Chonqing and Taiwan (Magombo 2003, Wang et al. 2005).

\section{Acknowledgements}

We thank the Curator of Bryophytes of PE for the loan of the specimen cited in the text and the Botanical Museum of the University of Helsinki for providing the facilities for the work.

\section{References}

Chiang, T.-Y. \& Lin, S.-H. 2001: Taxonomic revision and cladistic analysis of Diphyscium (family Diphysciaceae) of Taiwan. - Bot. Bull. Acad. Sin. 42: 215-222.

Deguchi, H., Ueno, J. \& Yamaguchi, T. 1997: Taxonomic notes on Diphyscium species with unipapillose leaf cells. - J. Hattori Bot. Lab. 82: 99-104.

Guo, S.-L., Enroth, J. \& Koponen, T. 2007: Bryophyte flora of Hunan Province, China. 11. Orthotrichaceae (Musci). - Ann. Bot. Fennici 44, Suppl. a: 1-34.
Högmander, J. \& Jie, G. X. 2000: Biodiversity action plan for Hunan Province, People's Republic of China. - Forestry Department of Hunan \& Metsähallitus Forest and Park Service, Helsinki.

Iwatsuki, Z. 1958: Correlations between the moss floras of Japan and the southern Appalachians. - J. Hattori Bot. Lab. 20: 304-352.

Iwatsuki, Z. 1976: Bryological miscellanies. XXI-XXII. J. Hattori Bot. Lab. 40: 139-149.

Iwatsuki, Z. 1992: The moss flora of Japan and its North American connections. - Bryobrothera 1: 1-7.

Koponen, T., Cao, T., Huttunen, S., Juslén, A., Peng, C., Piippo, S., Rao, P.-C., Vána, J. \& Virtanen, V. 2004: Bryophyte flora of Hunan Province, China. 3. Bryophytes from Taoyuandong and Yankou Nature Reserves, and Badagonshan and Hupingshan National Nature Reserves, with additions to floras of Mang-shan Nature Reserve and Wulingyuan Global Cultural Heritage Area. - Acta Bot. Fennica 177: 1-47.

Koponen, T., Enroth, J., Fang, Y.-M., Huttunen, S., Hyvönen, J., Ignatov, M., Juslén, A., Lai, M.-J., Piippo, S., Potemkin, A. \& Rao, P. 2000: Bryophyte flora of Hunan Province, China. 1. Bryophytes from Mangshan Nature Reserve and Wulingyuan Global Cultural Heritage Area. - Ann. Bot. Fennici 37: 11-39.

Koponen, T. \& Piippo, S. 2007: Bryophyte biodiversity in Hunan Province, China. - Chenia 9: 39-49.

Magombo, Z. L. K. 2002: New synonyms and combinations in the moss family Diphysciaceae M. Fleisch. (Musci). - Novon 12: 501-503.

Magombo, Z. L. K. 2003: Taxonomic revision of the moss family Diphysciaceae M. Fleisch. (Musci). - J. Hattori Bot. Lab. 94: 1-86.

Rao, P., Enroth, J., Piippo, S. \& Koponen, T. 1997: The bryophytes of Hunan Province, China: An annotated checklist. - Hikobia 12: 181-203.

Redfearn, P. L. Jr., Tan, B. C. \& He, S. 1996: A newly updated and annotated checklist of Chinese mosses. J. Hattori Bot. Lab. 79: 163-357.

Wang, M.-Z., Wu, P.-C., He, S. \& Magombo, Z. L. K. 2005: Diphysciaceae. - In: Wu, P.-C., Crosby, M. R. \& He, S. (eds.), Moss flora of China [English version], vol. 8: Sematophyllaceae-Polytrichaceae: 292-301. Science Press, Beijing \& Missouri Bot. Garden, St. Louis. 


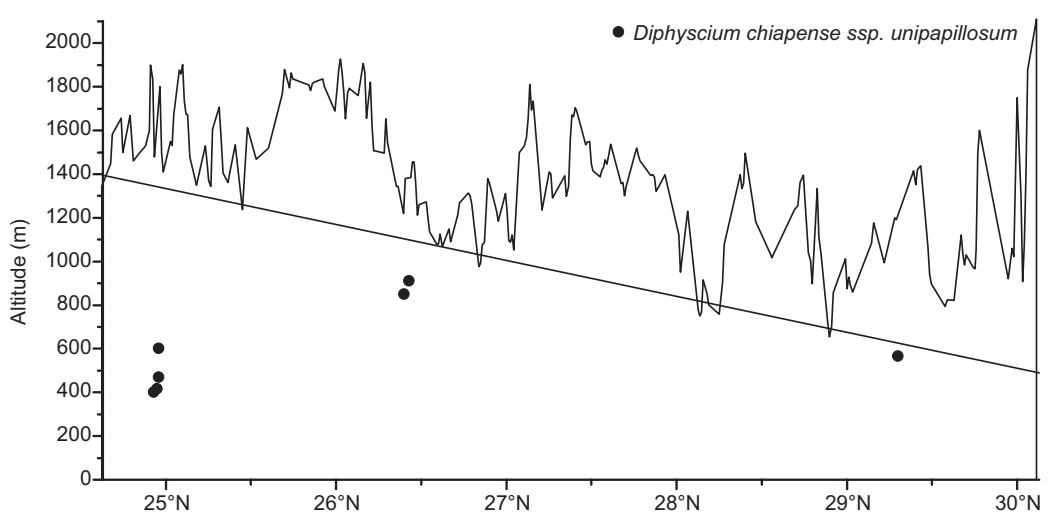

Appendix. The altitudinal distribution of the three

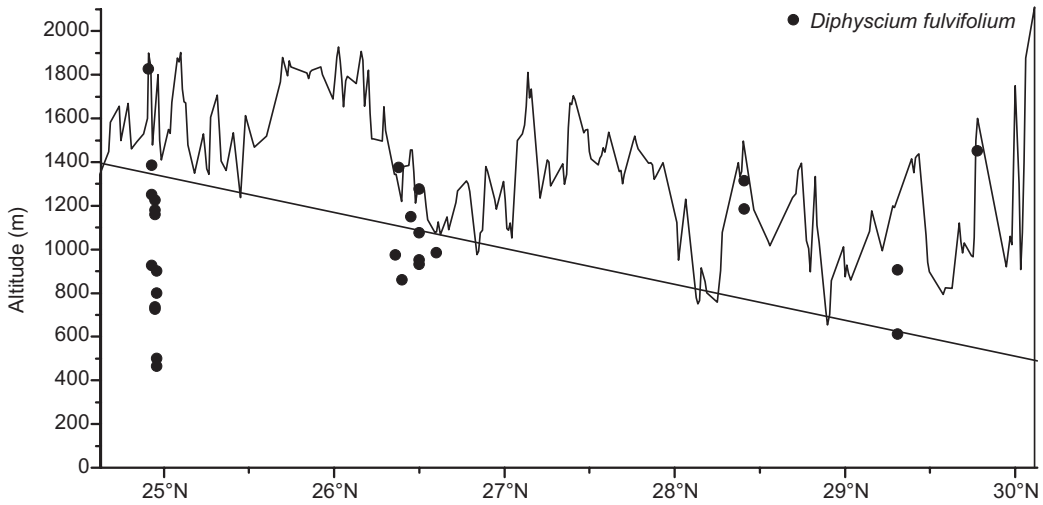
species of Diphyscium in Hunan province. The diagonal line is the upper border of warm temperate zone and the lower border of orohemitemperate zone. Diphyscium chiapense subsp. unipapillosum and $D$. mucronifolium were found only in warm temperate zone, while D. fulvifolium was evenly recorded from warm temperate and temperate zones.

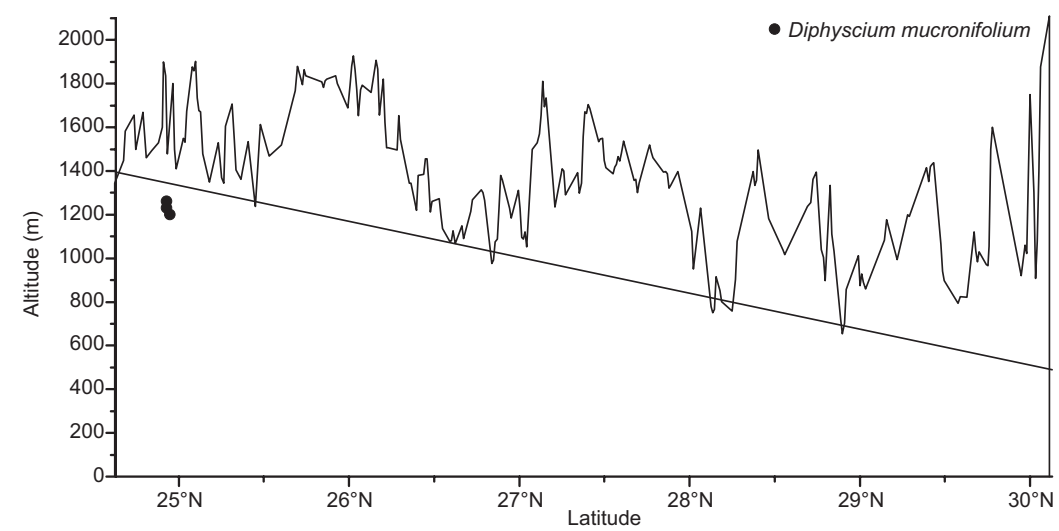

